\title{
The Teaching Design of Multimedia Web Page Design Based on the Flipped Classroom Mode
}

\author{
Jie Mao \\ Institute of Service Engineering, Hangzhou Normal University, Hangzhou, \\ P. R. China \\ Email: mao_jie@163.com
}

\begin{abstract}
To respond to the issues existing in the teaching of multimedia web page design, this paper has proposed a teaching mode based on the flipped classroom, where teachers provide teaching videos, courseware and other study resources before class, apply task-driven and interactive teaching methods during class, and make summaries and conduct extra exercises after class to inspire students to study, cultivate their study ability and enhance the teaching effect in class.
\end{abstract}

Keywords-Flipped classroom;task-driven; teaching design

\section{I.INTRODUCTION}

Multimedia web page design is a second-tier course among the public computer courses of our school and a required public computer course. It is oriented towards humanity majors and aims to cultivate students' ability of applying information technology based on their own major features. This course will help students grasp the basic knowledge and skills of designing the web page, developing multimedia web page factors and conducting innovation and application based on their own majors.

Against the background of uneven basis, the large number of students and complicated student structure, educators face the important issue of designing the teaching for the course of Multimedia Web Page Design based on students' study features and majors to maximize the teaching effect.
The teaching status quo of the course Multimedia Web Page Design :

(1) Teaching contents

Currently, the course of Multimedia Web Page Design describes the basic theory of website design and building, key technology, development and application. Its main contents include: the theoretical basis of website making; the basis of web page design, the theory of studying web page design, making web page pictures and web page effect pictures by Photoshop, a photo editing software; the basis of making web page animation: using web page animation factors by Flash, a animation editing software; basis of web page editing: sites, web page, patterns, html markup language and CSS files by using Dreamweaver(see Fig. 1)

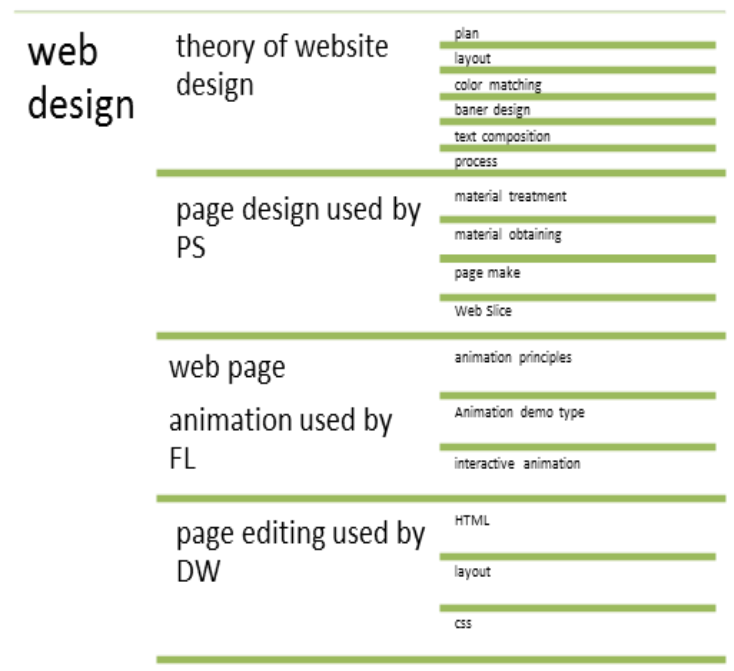

Figure 1 The Teaching Contents of Multimedia Web Page Design 
This course involves a wide range of knowledge points, and is a combination of art and technology. Thus, its teaching design should be based on the features and professional needs of students. It is oriented towards humanity majors and focuses on the frontground page design by multiple design tools, which might by improved by code editing as necessary.

Based on the experience of the school over the last few years, students can easily accept the artistic aspects of web page, such as color matching, pattern and other main design principles, but are obviously weak in the understanding and application of technology as far as their majors and foundation is concerned.

(2) Teaching methods

The course of Multimedia Web Page Design combines classroom teaching and exercise on the computer and is offered in 4 periods per week. The teacher teaches knowledge on web page editing in the multimedia-aided classroom by the one-to-many way; then students exercise on the computer. It applies the way of "teachingverification" method. Students passively receive knowledge in class, rather than thinking on their own, thus lacking judgment and imagination, let alone innovative thinking.

\section{II.FLIPPED CLASSROOM}

Flipped classroom originated from Woodland Park High School in Colorado in the spring of 2007, when chemistry teachers Jonathan Bergmann and Aaron Sams recorded the display of their lectures on PowerPoint by a screen capture software and posted them online in order to accommodate students who missed their classes. Soon, this teaching mode became popular.

Currently, the flipped classroom has become a new teaching mode that attracts the attention of educators around the globe. It completely overturns traditional teaching concepts and focuses on the initiative of students in learning and the internalization process of knowledge. In the flipped classroom, students enter the classroom with questions rather than passively learning and simulating; the teacher no longer teaches merely, but answers questions.

The flipped classroom has such obvious advantages as follows:

(1) students can rationally decide the teaching progress based on their own learning level;

(2) this teaching mode enriches teaching contents and widens taught information;

(3) it facilitates the revision for students.

\section{EXPLORATION ON THE TEACHING MODE OF} MULTIMEDIA WEB PAGE DESIGN BASED ON THE FLIPPED CLASSROOM

The flipped classroom switches the knowledge acquisition and internalization in the traditional education, differentiate various teaching links, decide teaching based on learning, i.e. learning takes place before teaching, thus realizing the transformation of teaching and learning methods.

\section{Step1 Pre-class self-study}

The main tasks of teachers before the class is to record the lecture, whose quality directly determines the interest and learning effect of students. Thus, teachers should start from two aspects: first, discompose the contents of one lecture based on knowledge points, which are recorded in a video separately; second, the recording time of a teaching video shall be within 15 minutes. This will facilitate the selective study of students.

\section{Step2: Task-driven classes and knowledge internalization}

Teachers inspire the initiative of students by using specific cases and tasks. In the first 5 minutes of class, they first display cases, make preliminary analysis of the knowledge points involved in them and conduct discussions among students where they interact with and answer questions of students. In the last 5 minutes of 
class, they summarize and evaluate the learning of every group.

\section{Step3: After-class exercises for consolidation}

Teachers solve issues in the recognition process of groups in a timely manner to carefully design after-class advanced exercises in the hope that constant exercises can help students consolidate what they have learned.

Based on the above teaching model and the Internet teaching platform, this paper takes the "DW" module as an example to show the specific flipped classroom process((see Table 1$)$.

Table 1 The Teaching Process of the Flipped

\begin{tabular}{|c|c|c|}
\hline \multicolumn{3}{|c|}{ Classroom } \\
\hline \multicolumn{3}{|c|}{ Pre-class } \\
\hline \multicolumn{2}{|c|}{ Teachers' activity } & $\begin{array}{l}\text { Students' } \\
\text { activity }\end{array}$ \\
\hline video & $\begin{array}{l}\text { Record four } \\
\text { videos,each of } \\
\text { which does } \\
\text { not exceed } 15 \\
\text { minutes: } \\
\text { 1.website building, } \\
\text { 2.structured web } \\
\text { page, } \\
\text { 3.web page layout, } \\
\text { 4.css }\end{array}$ & \multirow{4}{*}{$\begin{array}{l}\text { 1. Watch } \\
\text { teaching videos } \\
\text { through the } \\
\text { online platform; } \\
\text { 2. Check } \\
\text { teaching PPT } \\
\text { and learn about } \\
\text { the knowledge } \\
\text { about web page } \\
\text { production; } \\
\text { 3. Analyze } \\
\text { cases and find } \\
\text { solutions } \\
\text { issues in to } \\
\text { process of study } \\
\text { through } \\
\text { referring } \\
\text { relevant to } \\
\text { handbooks; } \\
\end{array}$} \\
\hline PPT & $\begin{array}{l}\text { Put down } \\
\text { knowledge points } \\
\text { involved in lectures } \\
\text { in a list }\end{array}$ & \\
\hline $\begin{array}{l}\text { resourc } \\
\text { es }\end{array}$ & $\begin{array}{l}\text { Cases and CSS } \\
\text { handbooks }\end{array}$ & \\
\hline $\begin{array}{l}\text { Upload } \\
\text { resourc } \\
\text { es to } \\
\text { teachin } \\
\text { g sites }\end{array}$ & $\begin{array}{l}\text { Including teaching } \\
\text { videos, teaching } \\
\text { PPT and outside- } \\
\text { the-classroom } \\
\text { resources }\end{array}$ & \\
\hline \multicolumn{3}{|c|}{ In class } \\
\hline $\begin{array}{l}\text { Put } \\
\text { forward } \\
\text { tasks }\end{array}$ & $\begin{array}{l}\text { Display the web } \\
\text { page effective } \\
\text { pictures and discuss } \\
\text { their layout and css }\end{array}$ & \multirow{3}{*}{$\begin{array}{l}\text { 1. Divide } \\
\text { groups based on } \\
\text { requirements; } \\
\text { 2. Each group } \\
\text { selects one } \\
\text { representative to } \\
\text { report } \\
\text { discussion } \\
\text { results }\end{array}$} \\
\hline $\begin{array}{l}\text { Group } \\
\text { discussi } \\
\text { on }\end{array}$ & $\begin{array}{l}\text { Based on students' } \\
\text { seats, five persons } \\
\text { per group }\end{array}$ & \\
\hline $\begin{array}{l}\text { Teachi } \\
\text { ng } \\
\text { guidanc } \\
\text { e }\end{array}$ & $\begin{array}{l}\text { Demonstrate } \\
\text { solutions to issues } \\
\text { existing in all } \\
\text { groups }\end{array}$ & \\
\hline & After class & \\
\hline
\end{tabular}

\begin{tabular}{|l|l|}
\hline 1. Collect students' works & 1. Upload works \\
2. Evaluate students'works & to FTP \\
3. Share excellent works & $\begin{array}{l}\text { 2. Review } \\
\text { teaching contents } \\
\text { through the online } \\
\text { platform }\end{array}$ \\
\hline
\end{tabular}

\section{IV.STUDENTS' FEEDBACK ON CLASSROOM}

\section{TEACHING DESIGN}

Through two terms of flipped classroom teaching practice, the paper learns about the understanding of students about the new teaching design by way of questionnaires. Two hundred and fifty questionnaires are distributed and 246 are effective.

About the attitude towards this course, 92\% "like the course", while $8 \%$ think it is unfit for them;about the use of pre-teaching resources, $75 \%$ think "the teaching videos provided by teachers are useful", 22\% "like the teaching of teachers", and 3\% think "PPT and files are rich and more helpful"; about the task-based teaching activities, $42 \%$ think they are "appropriate, rational and interesting" and they can "actively participate in interaction and exchanges", 57\% think "the contents are relative, and they can "actively think and grasp knowledge based on understanding", and 3\% are "not interested"; about after-class study, $21 \%$ "try to learn new contents through the teaching platform", $76 \%$ "study to finish tasks required by teachers", and 3\% "never studied".

Based on the results of questionnaires, students are satisfied with the new teaching design. Compared with the traditional one, the flipped classroom is more helpful to cultivate and improving students' ability of self-study, problem analysis and solving, interpersonal exchange and communication.

\section{CONCLUSION}

This course involved such wide contents as graphic treatment, web-page animation design and visual web page design. Based on the teaching arrangement of flipped classroom, it transforms the passive reception of students to 
active learning and provides them with more changes of participation in class. The teaching resources provided by teachers before class, such as videos and courseware, can better satisfy the needs of students with different levels and solve such issues as imbalanced basis, the large number of students and complicated student sources, so that they can select contents based on their own conditions, thus realizing differential teaching. The project-based synergy study, teacher-student interaction, case discussion and problem solving during class can better achieve the internalization of knowledge and inspire the initiative and creativeness of students.

However, teaching design of this course is not without problems and remains to be improved. The workload of recording lectures is huge; teachers need to control the speed and carefully design the contents; in addition, project design needs to combine the features of majors and satisfy the diversified needs of society towards talents.

\section{REFERENCES}

[1] Baker,J.W. The " classroom flip":Using web course management tools to become the guide by the side[A].Jacksonville,FL,2000.

[2] Bergmann,J,Sams,A. Flip your classroom:Reach every student in every class every day[M].Washington,DC:International Society for Technology in Education,2012.

[3] Fitzpatric,M. Classroom lectures go digital with video-on-demand[EB/OL].

http://www.nytimes.com/2012/06/25/us/25iht-

educside25.html,2012.

[4] Gerstein,J. The flipped classroom model:A full picture[EB/OL].

http://usergeneratededucation.wordpress.com/20

11/06/13/the-flipped-classroom-model-a-fullpicture,2012.

[5] Lage,M.J,Platt,G.J. The Internet and the inverted classroom $[\mathrm{J}]$.The Journal of Economic Education,2000,(01):11.
[6] Flipped classroom

defined[EB/OL].http://digitalsandbox.weebly.co m/flipped-classroom.html,2012. 